\title{
Caso exemplar de possessão: a pós-modernização de Mallarmé
}

\author{
Sérgio Medeiros
}

Pretendo comentar brevemente o sublime irônico de Mallarmé, um poeta da segunda metade do século XIX, utilizando a versão para o português, assinada por Augusto de Campos, do seu célebre poema "O Azul”. Essa tradução consta do livro Mallarmé, Perspectiva, 1991, que o próprio Augusto organizou, com Décio Pignatari e Haroldo de Campos; os poemas do autor francês estão na língua original e em português. No original, a palavra "azul" é repetida quatro vezes no verso final; na tradução brasileira, a palavra é repetida seis vezes, tendo o tradutor optado por essa solução ao omitir a frase que abre o verso, "Je suis hanté", após a qual o vocábulo "azul", acompanhado de ponto de exclamação, se repete quatro vezes em francês.

Permitam-me traçar rápidos comentários sobre a importância desse poema, antes de considerar a tradução de Augusto de Campos.

Paul Bénichou, no seu estudo Selon Mallarmé, afirma que o tema do poema é a situação do poeta entre o Real ignóbil (o abjeto, eu diria) e o Ideal inacessível (o Sublime). O azul, o alto, é o ideal, mas ele é considerado, no poema, da perspectiva do fracasso e da tortura. O azul, no plano simbólico, remete à noção, típica da imaginação 
romântica e moderna, de um Deus indiferente ao homem, de um Deus situado numa distância inacessível para a alma que clama por ele, sempre em vão. “'L'Azur, avec sa majuscule, n'est pas seulement le bleu du ciel que nous voyons; il est cet ideal lointain qui obsède les hommes" (Selon Mallarmé, p. 100), afirma Bénichou. Beleza, azul, céu, ideal são nomes e atributos da Divindade, mas de uma Divindade especialmente distante e indiferente ao destino humano. Por isso, numa reviravolta ao mesmo tempo irônica e cruel, da qual todo o pessimismo moderno é herdeiro, esse outro indiferente se tornará o Inimigo, a Divindade é o Inimigo do poeta. Se o Universo é informe e indiferente, como ainda advogar pela permanência do Belo, do harmonioso e do homogêneo na arte? O poeta declarará guerra ao azul, guerra ao ideal, e, num ato que beira a demência, segundo Bénichou, repetirá, encarando o vazio que é Deus, quatro vezes a terrível palavra "azul". O poema de Mallarmé mostraria, assim, "une sorte de dément en revolte vaine contre l'universe" (Selon Mallarmé, p. 101). Na tradução brasileira, o poema afirma: "O poeta incapaz que maldiz a poesia/ No estéril areal de um deserto de Dores."

Nesse poema, o azul é a obscuridade ("-O Céu é morto.-") e o sujeito é um mero pote de maquiagem deixado ao pé de um muro, muro de hospício ou de cemitério. Diz a tradução: “(...), desde que meu cérebro vazio,/ Como um pote de creme inerme ao pé de um muro, (...)". Essa imagem, a do homem-no-pote, a do crânio cheio de creme para maquiar a face, parece ecoar em outras imagens que a arte do século XX produziu, como o jarro liso e sem cor de Wallace Stevens, por exemplo, vaso que faz o mato crescer ao redor de si, no poema intitulado "Anedota do jarro", ou a grande bola falante do romance $O$ inominável, de Samuel Beckett, um personagem deformado que assim se descreve a si mesmo: "Enfiado, como um ramo, num pote profundo, cujos bordos me chegam à boca, à beira de uma rua pouco freqüentada nas proximidades dos matadouros, estou tranqüilo, finalmente" (O inominável, p. 60).

Enquanto o homem-no-pote de Beckett parece tranqüilo, o de Mallarmé, no poema que estou comentando, vive sua crise mais 
aguda, ou catastrófica, no verso final, enlouquecendo enquanto repete a palavra mais odiada, o azul. O poeta "proclame sa propre démence, et la prouve en répétant indéfiniment le nom de son ennemi" (Selon Mallarmé, p. 105), segundo Bénichou. O número 4 é aqui, de novo segundo o mesmo estudioso, sinal de repetição infinita, isto é, sinal de anomalia mental. "La rhétorique commune admet, depuis da Bible, la triple répétition comme figure reçue" (Selon Mallarmé, p. 105), argumenta Bénichou.

O sujeito mallarmaico é, segundo Pierre V. Zima, aquele que, tendo saído dos grandes "metarrelatos" (a fé cristã, por exemplo), agora só pode contar consigo mesmo, ou com seus recursos pessoais. A separação entre sujeito e objeto se consuma e o mundo perde sua unidade. O sujeito, não sendo mais autônomo, não poderá jamais dominar o acaso. Só lhe resta, como já disse, implorar em vão pela Divindade, para sempre indiferente ou inacessível. E, depois, declarar guerra a essa mesma Divindade, num ato de desencanto extremo. A Divindade é o inumano. A escritura de Mallarmé anunciaria o divórcio entre o belo e o sublime, na tentativa de levar a negatividade da sua arte até o inumano, uma das dimensões do sublime moderno, justamente.

Mas o sublime, por ser inumano, é ameaçador, ameaça o sujeito e finalmente o destrói. O sujeito ainda quer sobreviver ao contato com o ilimitado, com o informe, e declara seu maior inimigo o sublime. Nesse sentido, Mallarmé não é o poeta do sublime, mas do belo negativo, da subtração contínua. Por isso seu poema termina com um grito, "un cri déchirant qui réagit à l'irruption du sublime dans le beau et témoigne de la démence à laquelle risque de se livrer le sujet en tâchant de représenter le sublime irreprésentable" ( $L a$ négation esthétique, p. 69), afirma Zima. O deserto estende-se diante do poeta, que só apreende o vazio.

Ao comentar um poema posterior de Mallarmé, “Um lance de dados", Alain Badiou dirá que, nesse poema-testamento, a função do poeta "é fazer a escolha e a não-escolha equivalerem-se. Então suporta até o fim a nudez do local. E sobrevém a verdade, totalmen- 
Sérgio Medeiros. Caso exemplar de possessão: a pós-modernização de Mallarmé

te anônima, sobre o lugar desertado" (Pequeno manual de inestética, p. 70). Então, nesse espaço nu (a última página do poema visual) surgirá, de repente, como sabemos, a Constelação, um curso transcendente que parece, momentaneamente, negar o nada, o vazio, o inumano de que se falou atrás. Eis o enigma do último Mallarmé, um enigma nunca decifrado e que não poderei discutir aqui, pois nosso tema não é a Constelação, mas o Azul que a esconde, que a anula, sendo ele mesmo, porém, obscuridade e não claridade. São as trevas, e não azul, que propiciam, parece-me, o aparecimento dessa nostálgica ou necessária Constelação.

$\mathrm{Na}$ famosa carta de 27 de maio de 1867, ao seu amigo Eugène Lefébure, Mallarmé afirmou que escrevia a sua obra por eliminação. A negação estética era a tendência poética do período, por assim dizer, e teve, daí por diante, grande impacto na arte da primeira metade do século XX. Ou melhor, na arte de todo o século XX. Mallarmé, o Dante da Era Moderna, como já foi chamado, declarou na referida carta: "A Destruição foi a minha Beatriz."

Sou leitor de Mallarmé, poeta que releio continuamente, mas, por fidelidade à perspectiva histórica, ouso reformular a frase dele, adequando-a à realidade no nosso tempo: "A Multiplicação é a minha Beatriz." A eliminação e a destruição não poderiam ser perpetuadas na nossa época. A Constelação retorna, ressurge, talvez na Terra e não no Céu, refletida num espelho atual, que a deforma certamente.

Acredito que, se tivesse de definir o meu tempo, o nosso tempo, a partir da tradução de Mallarmé feita por Augusto de Campos, diria (ou essa tradução diria por si mesma) que este é o tempo da multiplicação paródica e alucinada, às vezes mecânica e inútil, multiplicação vazia. Não estamos mais sob o domínio da poética da subtração, da eliminação. A tradução de Augusto de Campos seria uma confirmação disso, ou não negaria pelo menos as minhas palavras.

A impossibilidade de representar um sublime irrepresentável, contudo, acabou levando Mallarmé também ao infinito terreno, à multiplicação na Terra. No final desse poema, "L'Azur", o poeta 
reconhece que é impossível dizer o indizível: "Je suis hanté. L'azur! l'Azur! l'Azur! l'Azur!" Ele multiplica a sua voz, multiplica as sílabas do poema sobre o fracasso, a impotência do poeta em dizer o indizível. Talvez eu devesse citar aqui as palavras de alerta de Jacques Rancière: "Il est temps de cesser de lire Mallarmé à travers les témoignages des rêves de ses vingt-cinq ans, ou à travers le projet anéanti du Livre" Mallarmé: La politique de la sirène, p. 11). Ou seja, é preciso dar ao "fracasso" do belo em atingir o sublime uma interpretação que não reduza a questão a uma crise pessoal, íntima.

Na tradução desse poema sobre o sublime moderno e inumano, Augusto de Campos escreveu simplesmente, assumindo a multiplicação pós-moderna: “O Azul! O Azul! O Azul! O Azul! O Azul! O Azul!" O vocábulo inimigo, o vocábulo danoso é repetido seis vezes, com uma facilidade notável. É o infinito terreno, ao alcance dos homens. Sublime abjeto e material, paródia do sublime espiritual ou transcendente.

Porém, isso não é Mallarmé, isso, o demente que precisa dizer seis vezes a mesma palavra para representar o infinito banal, alongando exageradamente a série, isso é a nossa época, que multiplica o mundo e a linguagem, recorrendo ao exagero barroco. Para Mallarmé, o infinito estava no número 4, bastava o seu poema repetir uma palavra quatro vezes para tudo cair no desespero, no deserto moderno (cf. Pierre Zima). O poeta impotente e mudo, ou quase mudo, ia assim além do 3, o número sagrado, a contagem bíblica, mas não lhe era necessário o 6, como é necessário para Augusto de Campos.

O pós-moderno, para mim, está resumido nessa versão brasileira e paulistana de Mallarmé, versão monótona e infinita, que Augusto de Campos, mais exagerado e dionisíaco do que geralmente se admite, transformou num sublime abjeto, paródico, mecânico, algo tonto, risível, uma série explícita: azul, azul, azul, azul, azul, azul... Algo mais monótono do que desesperado.

Mallarmé não poderia dizer isso, nós podemos e ficamos balbuciando essas sílabas... 
Sérgio Medeiros. Caso exemplar de possessão: a pós-modernização de Mallarmé

Recentemente, conversei com o estudioso argentino da poesia concreta brasileira, Gonzalo Aguilar, professor da Universidade de Buenos Aires, e um dos temas da conversa foi a tradução desse poema de Mallarmé (cf. www.centopeia.net ). Para Aguilar, Augusto de Campos substitui, na sua tradução, a fala sobre a possessão pela possessão mesma, por isso repete seis vezes a palavra azul e não quatro, como Mallarmé fez. Isso teria ocorrido porque, para Augusto, a tradução é um ato de possessão, ou seja, o tradutor teria buscado produzir, na sua época, um texto tão original quanto aquele que lhe serviu de fonte, a fim de melhor apropriar-se do texto e converterse, perante o leitor, numa voz privilegiada, ou decerto tão autorizada quanto a voz do próprio Mallarmé. Na tradução como ato de possessão, o tradutor assume finalmente a autoria do texto. Por isso, nos livros de traduções dos irmãos Campos, só o nome dos tradutores vêm na capa, como verdadeiros autores daqueles textos impressos em português.

Outra observação interessante que me fez Aguilar refere-se à leitura do poema "O Azul" no mundo hispano-americano. Existe uma tradição de leitura, que remonta a Ruben Darío, autor de um estudo sobre Mallarmé. Segundo essa tradição, a repetição de palavras é interpretada como fórmula ritual ou sibilina. Não se trata de demência, segundo a leitura que propus acima, mas de uma tentativa de recuperar a força secreta das palavras, repetindo-as num novo salmo musical, após o fim da religião.

Talvez pudéssemos pensar numa religião demente, numa religião para dementes..., a mais imemorial de todas. Aquela que não deixa de amaldiçoar o Ideal, a Divindade. Seria essa a religião dos tradutores que declararam e ainda declaram guerra à tradução ideal, sublime, divina?

Concluo dizendo que considero "O Azul" uma das melhores traduções de Augusto de Campos. Talvez a tradução que mais me agrade. 
Cadernos de Literatura em Tradução, n. 9, p. 9-15

\section{Bibliografia}

BADIOU, Alain. Manual de inestética. São Paulo: Estação Liberdade, 2002.

BECKETT, Samuel. O inominável. Lisboa: Assírio \& Alvim, 2002. BÉNICHOU, Paul. Selon Mallarmé. Paris: Gallimard, 1995.

CAMPOS, Augusto de et al. Mallarmé. São Paulo: Perspectiva, 1991. MALLARMÉ, Stéphane. Correspondance/Lettres sur la poésie. Paris: Gallimard, 1995.

RANCIÉRE, Jacques. Mallarmé: La politique de la sirène. Paris: Hachette, 1996.

STEVENS, Wallace. Poemas. São Paulo: Companhia das Letras, 1987. ZIMA, Pierre V. La négation esthétique. Paris: L'Harmattan, 2002. 